\title{
食品のアミノ酸分析について Amino Acid Analysis of Foods
}

\author{
試料加水分解時の塩酸量の影響について
}

The effects of the quantity of hydrochloric acid for hydrolysis

(昭 和 42 年 2 月 9 日 受 理)

\author{
劒持久保田村真八郎 \\ (Kuniko Kenmochi) (Shinpatirô Tamura)
}

On the determination of amino acid content of foods which contain a large amount of carbohydrate, the effects of the quantity of $\mathrm{HCl}$ for hydrolysis of samples were studied. It has been made evident by the experiment, that the quantity of $\mathrm{HCl}$ gives a significant influence on the amino acid recovery.

Hydrolysis were performed with various amount of $6 \mathrm{~N} \mathrm{HCl}$, from 1 to 1,000 times against sample weight, for 24 hours at $110^{\circ} \mathrm{C}$. Amino acid analysis was carried out on the hydrolyzates of isolated soybean protein and rice protein, with or without starch, using a Beckman Spinco model $120 \mathrm{~A}$ amino acid analyzer. The ratio of protein to carbohydrate was $1: 10$.

As far as the hydrolyzates of isolated protein without starch, the amino acid values showed no significant changes by adding more than 100 times the amount of $\mathrm{HCl}$ against the sample. In the case of hydrolyzates of samples with starch, there were differences between soybean protein and rice protein. On the hydrolyzates of soybean protein with starch, all the amino acid values of the sample were found to be quite similar to the values of the hydrolyzates of soybean protein without starch obtained by adding more than 100 times amount of $\mathrm{HCl}$ against the sample. And even by adding $\mathrm{HCl}$ only 10 times against the sample, good recoveries except for tyrosine were obtained. But in the case of rice protein with starch it was not good enough to add 100 times amount of $\mathrm{HCl}$ against the sample, since tyrosine, serine and arginine were notably lost. Especially the recovery of tyrosine decreased by adding 1,000 times amount of $\mathrm{HCl}$ against the sample.

In conclusion, on the determination of amino acid content of foods, satisfactory values were obtained except for tyrosine and arginine by adding more than 100 times amount of $\mathrm{HCl}$ against the sample for hydrolysis.

著者らは以前に，たんぱく質にでんぷんを混合した試 料のアミノ酸測定について報告) した。その報告中で， でんぷん混合試料に対して 10 倍量の $6 \mathrm{~N}$ 塩酸を加えて 加水分解する場合にアミノ酸の破壊による損失が起こり やすく, その結果, 測定值が著しく低くなるアミノ酸は チロシン, メチオニン, セリン, アルギニンの 4 つであ り，またその他のアミノ酸の測定值も低くなることを明 らかにした。一方, Moore ${ }^{2)}$ はでんふん混合試料に対し 約 100 倍程度（たんぱく質に対し 1,000 倍量）の $6 \mathrm{~N}$ 塩 酸を加えて加水分解すれば, アミノ酸はほほ定量的に回 収されるので, 食品のアミノ酸分析の場合にも多量の塩 酸を加えて加本分解する方法が利用できるであるらと述 べた。本報告では試料に対して加える塩酸量を 1 倍から
1,000 倍の範囲で変えて加水分解を行ない, 加水分解液 のアミノ酸含量を測定し, 塩酸量が各アミノ酸の測定値 に及は影響を明らかにした結果について述べる。

\section{実験}

分析試料として，白米粉から調製した白米たんぱく質 (ク゚ルテリン)、へキサン脱脂大豆粉から調慗した大豆た んぱく質，および白米でんぷんを用いた。

たんぱく質単独試料およびたんぱく質に対し10 倍量 のでんぷんを混合した試料（でんぷん混合試料）を加水 分解用のガラス管にはかり込み，この試料量に対し 1 倍 から 1,000 倍までの範囲で変えた量の $6 \mathrm{~N}$ 塩酸を加え， 封管したのち, $110^{\circ} \mathrm{C} て ゙ 24$ 時間加水分解し, その各加 
栄盖と食糧

第 1 表

単位: アミノ酸 $\mathrm{mg} /$ たんぱくg

\begin{tabular}{|c|c|c|c|c|c|c|c|c|c|c|}
\hline \multirow{3}{*}{ アミ，酸 } & \multirow{3}{*}{$\begin{array}{l}\text { で } \\
\text { ん̊ } \\
\text { L }\end{array}$} & \multicolumn{5}{|c|}{ 大豆たんぱく質 } & \multicolumn{4}{|c|}{ 白米たんぱく質 } \\
\hline & & \multicolumn{4}{|c|}{ 塩 酸 量(対試料) } & \multirow{2}{*}{$\begin{array}{r}\text { 平均値 } \\
\mathrm{mg}\end{array}$} & \multicolumn{3}{|c|}{ 塩酸量（対試料） } & \multirow{2}{*}{$\begin{array}{r}\text { 平均値 } \\
\mathrm{mg}\end{array}$} \\
\hline & & 1,000倍 & 100倍 & 10倍 & 1 倍 & & 1,000倍 & 100倍 & 10倍 & \\
\hline Lys. & $\overline{+}$ & $\begin{array}{l}52.1 \\
52.6\end{array}$ & $\begin{array}{l}53.4 \\
51.9\end{array}$ & $\begin{array}{l}54.8 \\
54.9\end{array}$ & 43.9 & 53.4 & $\begin{array}{l}27.5 \\
27.8\end{array}$ & $\begin{array}{l}27.3 \\
27.6\end{array}$ & 24.9 & 27.4 \\
\hline His. & $\overline{+}$ & 21.7 & $\begin{array}{l}21.9 \\
22.9\end{array}$ & $\begin{array}{l}23.3 \\
18.8\end{array}$ & 18.1 & 22.3 & & & & \\
\hline Arg. & $\overline{+}$ & $\begin{array}{l}69.0 \\
65.8\end{array}$ & $\begin{array}{l}69.7 \\
65.3\end{array}$ & $\begin{array}{l}69.8 \\
61.9\end{array}$ & 31.8 & 69.5 & $\begin{array}{l}84.9 \\
86.1\end{array}$ & $\begin{array}{l}81.9 \\
73.0\end{array}$ & 57.9 & 83.4 \\
\hline Asp. & $\bar{t}$ & $\begin{array}{l}107.1 \\
107.6\end{array}$ & $\begin{array}{l}106.5 \\
106.0\end{array}$ & $\begin{array}{l}107.7 \\
111.9\end{array}$ & 92.3 & 107.1 & $\begin{array}{l}97.4 \\
93.7\end{array}$ & $\begin{array}{l}93.3 \\
99.6\end{array}$ & 89.3 & 95.4 \\
\hline Thr. & $\overline{+}$ & $\begin{array}{l}33.6 \\
34.0\end{array}$ & $\begin{array}{l}33.5 \\
33.9\end{array}$ & $\begin{array}{l}33.1 \\
34.7\end{array}$ & 25.9 & 33.4 & $\begin{array}{l}33.9 \\
31.9\end{array}$ & $\begin{array}{l}30.3 \\
30.5\end{array}$ & 27.0 & 32.1 \\
\hline Ser. & $\overline{+}$ & $\begin{array}{l}45.5 \\
44.9\end{array}$ & $\begin{array}{l}45.2 \\
45.1\end{array}$ & 46.2 & 36.9 & 45.4 & $\begin{array}{l}51.5 \\
48.7\end{array}$ & $\begin{array}{l}41.5 \\
41.6\end{array}$ & 37.7 & 51.5 \\
\hline Glu. & $\bar{t}$ & $\begin{array}{l}186.8 \\
183.0\end{array}$ & $\begin{array}{l}183.1 \\
183.6\end{array}$ & $\begin{array}{l}184.8 \\
191.3\end{array}$ & 162.8 & 184.9 & $\begin{array}{l}193.4 \\
183.7\end{array}$ & $\begin{array}{l}186.6 \\
188.6\end{array}$ & 172.3 & 190.0 \\
\hline Pro. & $\overline{+}$ & $\begin{array}{l}46.8 \\
50.8\end{array}$ & $\begin{array}{l}48.1 \\
49.1\end{array}$ & $\begin{array}{l}48.3 \\
50.7\end{array}$ & 40.8 & 47.7 & $\begin{array}{l}43.3 \\
38.4\end{array}$ & $\begin{array}{l}40.1 \\
41.4\end{array}$ & 37.3 & 41.7 \\
\hline Gly. & $\overline{+}$ & $\begin{array}{l}37.7 \\
39.1\end{array}$ & $\begin{array}{l}38.5 \\
38.7\end{array}$ & $\begin{array}{l}39.3 \\
39.7\end{array}$ & 33.6 & 38.5 & $\begin{array}{l}42.7 \\
40.9\end{array}$ & $\begin{array}{l}41.6 \\
38.9\end{array}$ & 38.1 & 42.2 \\
\hline Ala. & $\overline{+}$ & $\begin{array}{l}35.5 \\
36.5\end{array}$ & $\begin{array}{l}36.6 \\
36.9\end{array}$ & $\begin{array}{l}38.3 \\
38.4\end{array}$ & 34.0 & 36.8 & $\begin{array}{l}51.3 \\
48.7\end{array}$ & $\begin{array}{l}50.2 \\
50.5\end{array}$ & 47.3 & 50.8 \\
\hline Val. & $\bar{t}$ & $\begin{array}{l}42.3 \\
43.5\end{array}$ & $\begin{array}{l}43.6 \\
43.6\end{array}$ & $\begin{array}{l}43.8 \\
44.3\end{array}$ & 32.9 & 43.2 & $\begin{array}{l}59.6 \\
57.8\end{array}$ & $\begin{array}{l}60.4 \\
57.5\end{array}$ & 52.4 & 60.0 \\
\hline Ileu. & $\bar{t}$ & $\begin{array}{l}41.9 \\
41.0\end{array}$ & $\begin{array}{l}41.0 \\
41.1\end{array}$ & $\begin{array}{l}42.4 \\
41.2\end{array}$ & 29.6 & 41.8 & $\begin{array}{l}41.6 \\
39.9\end{array}$ & $\begin{array}{l}42.0 \\
39.7\end{array}$ & 36.3 & 41.8 \\
\hline Leu. & $\overline{+}$ & $\begin{array}{l}68.7 \\
68.0\end{array}$ & $\begin{array}{l}67.4 \\
69.3\end{array}$ & $\begin{array}{l}71.5 \\
70.1\end{array}$ & 54.9 & 69.2 & $\begin{array}{l}82.6 \\
78.7\end{array}$ & $\begin{array}{l}81.9 \\
81.2\end{array}$ & 71.7 & 82.3 \\
\hline Tyr. & $\bar{t}$ & 30.9 & $\begin{array}{l}30.0 \\
30.2\end{array}$ & $\begin{array}{l}31.3 \\
13.4\end{array}$ & 3.4 & 30.7 & $\begin{array}{l}54.5 \\
31.5\end{array}$ & $\begin{array}{l}53.3 \\
32.0\end{array}$ & 21.0 & 53.9 \\
\hline Phe. & $\bar{t}$ & $\begin{array}{l}45.2 \\
45.1\end{array}$ & $\begin{array}{l}44.5 \\
45.2\end{array}$ & $\begin{array}{l}47.7 \\
44.1\end{array}$ & 30.9 & 45.8 & $\begin{array}{l}54.9 \\
52.5\end{array}$ & $\begin{array}{l}56.8 \\
54.0\end{array}$ & 44.3 & 55.9 \\
\hline
\end{tabular}

水分解液についてアミノ酸の分析を行なった。アミノ酸 の分析にはベックマン・スピンコ幣のアミ/酸分析計を 用いた。分析法の詳細は以前に報告3) したすのと同様で ある。

大豆たんぱく質の場合は，たんぱく質単独試料では塩 酸量を 10 倍，100倍，1000倍にした 3 点の加水分解液， でんふん混合試料では塩酸量を 1 倍， 10 倍，100倍， 1,000倍（この量はでんぷん混合試料量に 対してである から，試料中のたんぱく質量に対してはそれぞれ 10 倍 〜10,000倍になる）にした 4 点の加水分解液, 合計 7 点 のアミノ酸分析を行なった。

白米たんぱく質の場合は，たんぱく質単独試料につい
ては塩酸量を 100 倍, 1,000 倍にした 2 点の加水分解夜, でんぷん混合試料では塩酸量を 10 倍, 100倍, 1,000倍 （試料中のたんぱく質量に対してはそれぞれ 100 倍, 10,000 倍) にした 3 点の加水分解液, 合計 5 点のアミ, 酸分析を行なった。

結果

以上の測定結果を第 1 表に，また第 1 表の数値から計 算した各アミノ酸の回収率を第 2 表に示した。

回収率はたんぱく質単独試料の測定值（大豆たんぱく 質では 3 点, 白米たんぱく質では 2 点) の平均値を 100 として求めた。たたし，白米たんぱく質のセリンにおい 
第 $\quad 2$ 表

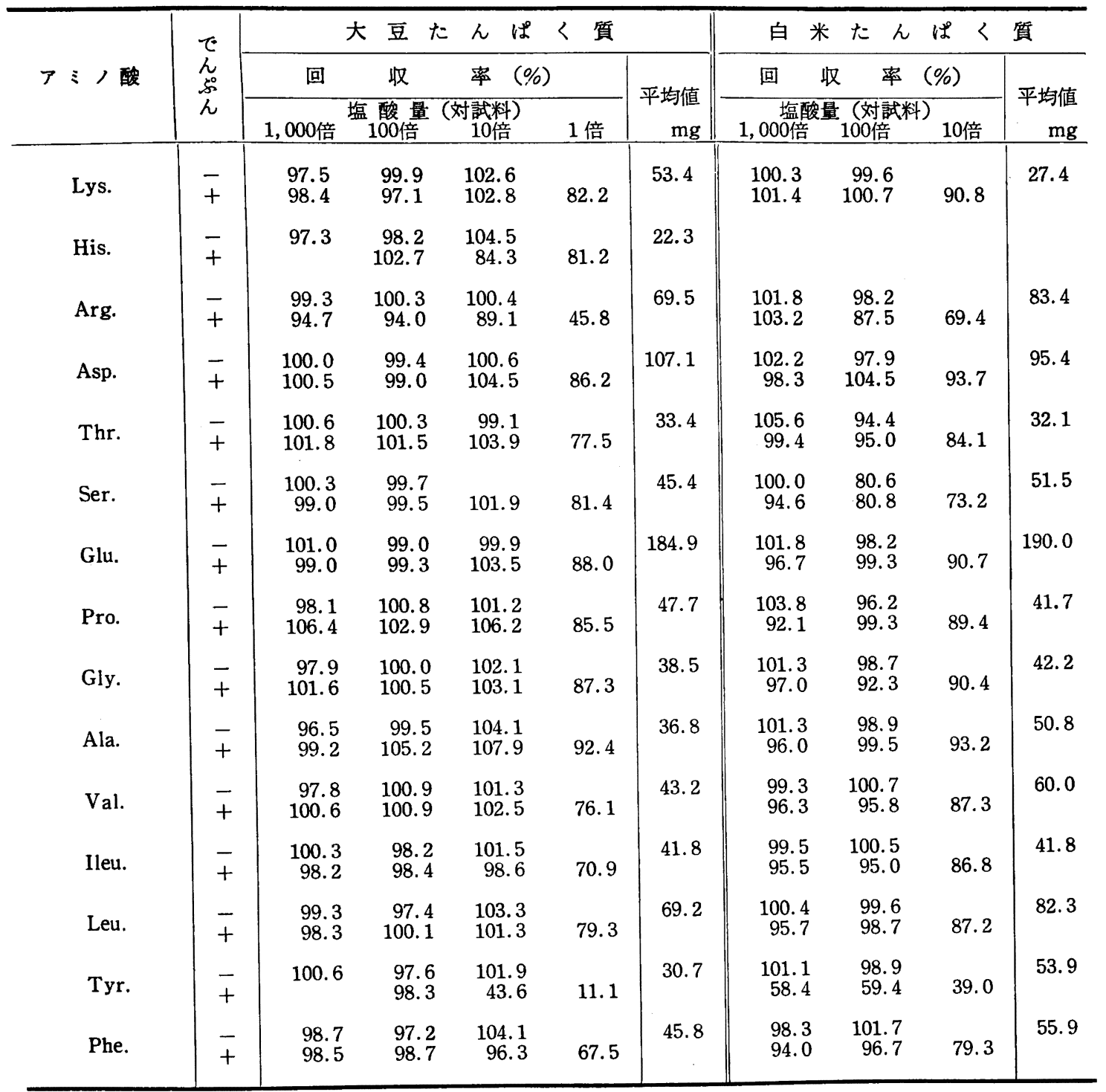

ては, 対試料塩酸量 100 倍の測定値は著者らの研究室の アミノ酸分析技術の水準（相対誤差約 $5 \%$ ）から考元て 誤差範囲をこえた有意のものと認められるので,これを 除き, 対試料塩酸量 1,000 倍の測定値を用いた。

\section{考察}

大豆たんぱく質の場合，たんぱく質単独試料のときは 加える塩酸量が10倍, 100倍, 1,000倍と変化しても, す ペてのフミノ酸の測定值は変らないと考えられる。でん ぷん混合試料のときは, 加え西塩酸量が試料に対して 100倍および 1,000 倍ではたんぱく質単独試料の場合と差 がない測定値が得られるが，10倍（対たんぱく質100倍）
の場合は, チロシン (43.6\%), ヒスチジン (84.3\%), アルギニン (89.1\%) の3アミノ酸については低い値が 得られた。また，塩酸量が対試料 1 倍（対たんぱく質 10倍, 実際には加水分解とい5より焦がすとい5状態に 近い) の場合はすべてのアミノ酸の測定値が低くなり, とくにチロシン(11.1\%), アルギニン $(45.8 \%)$ が著し W。

白米たんぱく質の場合, たんぱく質単独試料のときは 塩酸量 100 倍と 1,000 倍とではセリンを除いてはアミノ 酸測定值に差がないと考えられるが，でんぷん混合試料 の場合は塩酸量が対試料 100 倍（対たんぱく質1,000倍） では,チロシン(59.4\%)，セリン(80.8\%), フルギニン 
(87.5\%) の測定值が低くなり, 対試料 1,000 倍（対た んぱく質10,000倍）の場合でもチロシンの澌定值は低い 回収率 (58.4\%) しか得られなかった。また塩酸量が対 試料10倍（対たんぱく質 100 倍）の場合はすべてのアミ ノ酸が，かなり低い湘定値となり，とくにチロシン(39.0 \%), アルギニン (69.4\%), セリン (73.2\%) では回収 率の低下が著しく, 以前の実験結果”とはほ同様であっ た。

これらのことを比較してみると，でんぷん混合試料の 加水分解の場合, 大豆たんぱく質では混合試料に対し, 100 倍の塩酸量でよいと考えられるが, 白米たんぱく質 では 100 倍の塩酸量では不十分と考えられ，チロシン， セリン, アルギニンの測定值が低くなり, 混合試料に対 し 1, 000 倍量ですなお千ロシンの測定值は低くなる。し たがって, 炭水化物含量の多い食品, 飼料などのアミ， 酸分析にあたっては, 試料に対して, 100〜1,000倍量程 度の多量の塩酸を用いて加水分解すれば, チロシン, セ リン, アルギニン以外のアミノ酸については共存炭水化 物による損失からくる測定値の低下をまねかれると考兄 られる。
要 約

大豆たんぱく質，白米たんぱく質およびこれらに米で んぷんを加えたすのの計 4 種の試料について, 塩酸量を 試料に対して 1 〜 1,000 倍の範囲で变えて加水分解を行 なって，フミノ酸分析をし，塩酸量の多少がフミノ酸測 定値に及ほす影揰を考察した。たんぱく質単独試料では 試料に対して 100 倍以上の塩酸量で白米たんぱく質の七 リンを除いては、ほほ満足すべき値を得た。でんぷん混合 試料では，たんぱく質が大豆たんぱく質の場合は試料の 100 倍以上の塩酸量があれば，たんぱく質単独試料と同 じ測定値を示したが, 白米たんぱく質の場合は試料の100 倍の塩酸量では, チロシン, セリン, アルギニンの測定 值が低く，1,000 倍の塩酸量でもチロシンの測定値は低 かった。

\section{文献}

1）田村真八郎，劒持久仁子 : 農化, 37, 611 (1963)

2) Moore, S.: J. Biol. Chem., 238, 235 (1963)

3) 田村真八郎, 劒持久化 : 農化, 37, 278 (1963)

（農林省食糧研究所）

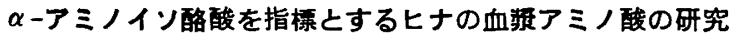

非代謝性 アミノ酸の一つである $\alpha$-アミノイソ酪酸 (AIBA) は, ヒナにおけるアミノ酸吸収の研究の指標 として利用できる。

まず結晶つミノ酸混合物を使用した基本食に AIBAを 0〜1.5\%添加した飼料を，間隔を扎いて投与し，最終摂 取時の 30 分のちに採血して血漿中のアミノ酸量を測定 した。血嶈中の AIBA 量は飼料中に添加した量とよく 比例し, 他のアミノ酸組成は飼料中の AIBA によって 影整を受けなかった。次に基本食の丁ミノ酸混合物の代 りにリジン，メチオニンがそれぞれ欠そしているゴマ粉
と大豆粉を用いた飼料に制限アミノ酸を添加したもの, しないすのについてそのいずれにす $0.5 \%$ AIBA を 添加して同様に血漿つミノ酸を測定した。そしてAIBA を指標にすることによって,インバランスな食餌のアミ ノ酸吸収は, ハシランスのとれた食慨のアミノ酸吸収ほど 速くないことが明らかになった。（表 6)

Use of $\alpha$-Aminoisobutyric Acid as an Internal Indicator in Chick Plasma Amino Acid Studies. by Smith R.E. : J. Nutrition, 89 ( 3 ), 276 282 (1966)

(煀井) 